\title{
A System of Professions Approach to Reducing Heat Exposure in Cuyahoga County, Ohio
}

\author{
NICHOLAS B. RAJKOVICH
}

Volume 4, 2016

http://dx.doi.org/10.3998/mjs.12333712.0004.007

Department of Architecture, The State University of New York at Buffalo

\section{ABSTRACT}

Each year in the United States, more people die from heat waves than any other type of natural disaster. Climate change models predict an increase in extreme heat, especially in the Midwest. There have been limited efforts to describe how professionals define, implement, and evaluate strategies to reduce heat stress, though such taxonomy would support cross-disciplinary collaboration and communication. By examining the results of semi-structured interviews with public officials from the health, building, and urban policy sectors, this paper explores the system of professions involved in reducing exposure to heat stress in Cuyahoga County, Ohio. A system of professions approach links professionals to the work they consider their jurisdiction, such as providing cooling centers, weatherizing homes, or developing physical plans; it also describes their interrelations to identify gaps, barriers, and conflicts that limit coordination and collaboration. Greater Cleveland is the focus of this study because several recent climate assessments have identified the region as extremely vulnerable to increased temperatures. Interviews confirmed that professionals define issues related to temperature in the built environment differently. This results in different diagnoses, methods of inference, and treatments of temperaturerelated issues. Only three strategies—energy efficiency, air-conditioning, and indoor air quality-were discussed by interviewees from all three sectors; this indicates disconnects among professions regarding other important approaches. The interviews also confirmed that differences in priorities can cause conflict among policy sectors. 
Working collaboratively to resolve these differences is an important first step to reduce future heat-related mortality in the face of climate change.

\section{Introduction}

Each year in the United States, more people die from heat waves than from any other type of natural disaster (CDC, 2009). The National Climate Assessment projects an increase in the risk, intensity, and duration of extreme heat events over the next century due to global warming (Melillo, Richmond, \& Yohe, 2014). Fatalities associated with increased temperatures occur primarily in cities, in part due to the urban heat island effect (Luber \& McGeehin, 2008).

To understand heat-related exposure in cities, this research draws on insights from the environmental health sciences, building science, and urban climate literatures. However, while issues of health, residential energy use, and the urban heat island are interconnected, the responses proposed by policy communities are not well coordinated (Strengers \& Maller, 2011). This disconnect can lead to an inefficient use of resources and efforts that contradict one another.

For example, a number of authors in the environmental health sciences have advocated for the installation of residential air-conditioning to reduce exposure to high temperatures indoors (Keatinge, 2003; Semenza et al., 1996). This is because cities with higher air-conditioning prevalence have lower levels of heat-related mortality (Anderson \& Bell, 2009; Braga, Zanobetti, \& Schwartz, 2002; Chestnut, Breffle, Smith, \& Kalkstein, 1998). While these air-conditioning systems reduce interior temperatures, they increase household energy consumption, undoing the work of building scientists whose primary concern is energy efficiency (Guy \& Shove, 2000). In addition, the cooling system exhausts waste heat from the house to the atmosphere; this strengthens the urban heat island effect (O'Neill et al., 2009).

To address this type of conflict, connections need to be made among the environmental health sciences, building science, and urban climate communities. Focusing on Cuyahoga County, Ohio, this research attempts to forge a link among these fields by examining how professionals define, implement, and evaluate strategies to reduce heat exposure because several authors have claimed that such a taxonomy might support cross-disciplinary collaboration and communication (Blanco et al., 2009; Maller \& Strengers, 2011; O’Neill et al., 2009; T. R. Oke, 2006). This system of professions approach links professionals (e.g., public health officials, architects, urban planners) to the work they consider their jurisdiction, such as providing 
cooling centers, weatherizing homes, or developing plans (Abbott, 1988; Janda \& Killip, 2013).

Cleveland and its suburbs are the focus of the study because several nationallevel assessments of heat vulnerability identified the region as being vulnerable to high temperatures due to an older population, poor quality housing stock, a lack of central air-conditioning, and high quantity of impervious surfaces (Altman et al., 2012; Reid et al., 2009; Staudt \& Inkley, 2009). Although Northeast Ohio is an extreme case, healthy housing and environmental planning programs developed in Greater Cleveland have been used as a template for other cities in the United States (EPA, 2012; Jacobs, Kelly, \& Sobolewski, 2007); the results may be useful for climate change planning in cities like Detroit, Toledo, and Buffalo.

\section{Literature Review}

A number of authors have advocated for increased access to air-conditioning as a way to reduce heat-related morbidity and mortality (Keatinge, 2003; Semenza et al., 1996). However, Strengers and Maller (2011) argue that we need a better understanding of cooling practices, including the processes that drive adoption of certain technologies. In a study of Australian households, they found that policy responses to high temperatures have become locked in; this keeps policymakers from considering alternatives like natural ventilation and urban heat island management. They also found that differences in definitions leads to conflicts among the health, housing, and energy sectors (Ibid., 155).

These policy sectors are a broad group of individual, organizational, and institutional entities that focus on improving the health, housing, or urban environments of their constituents. A policy sector is similar in concept to an advocacy coalition (Sabatier \& Weible, 2007) or a discourse coalition (Hajer, 1995) but is broader in scope. Policy sectors can span multiple levels to include local, state, and federal agencies and non-governmental organizations.

Three policy sectors are engaged with the issue of heat stress in cities: health, building science, and the urban environment. These sectors are aligned with the professions of public health, architecture, and urban planning. Although these professions emerged from a common historical root (Corburn, 2009; Dagenhart \& Sawicki, 1992), they take very different approaches to improving quality of life for the public. While authors have used these three professions as examples to describe the sequence of professionalization (Wilensky, 1964) or the monopoly they may hold 
over decision-making processes (Fischer, 2000; Larson, 2013), this paper focuses on their interrelations to identify the gaps, barriers, and conflicts that may limit coordination and collaboration around the issue of reducing exposure.

The focus is on professionals because they are experts who operate within the "hidden hierarchies of policy communities" and have a significant influence on policy definition and implementation of solutions (Fischer 2000, 22). Janda and Parag (2013) believe that the importance of professionals is often overlooked in the social sciences; they argue that professionals have an important role in the "middle" as mediators between the government and the public. In their article, they claim that professionals are "middle-out" actors who work upstream to government, downstream to clients and customers, and sideways among other groups and organizations working in their area of expertise (Janda and Parag, 2013).

Because the goal is not to understand how a profession emerges, or to construct a complete sociology of these three professions, a profession is therefore broadly defined as an occupational group that has an abstract skill requiring extensive training. These abstract skills are not applied in a routine fashion; they require application on a case-by case basis depending on the situation (Abbott 1988, 7). This definition focuses on the knowledge systems used to define a problem and on the constitution of professional work (Ibid., 9).

\subsection{A System of Professions Framework}

A system of professions approach (Abbott, 1988) describes how professional groups define their work and establish jurisdictions over a problem; it is an ecological model that attempts to explain how professions interact (Henn, 2013). To define his framework, Andrew Abbott identifies three terms to label key processes: diagnosis, treatment, and inference (Ibid., 40).

Diagnosis is the analysis of the cause of a condition, situation, or problem. Treatments are the techniques or actions customarily applied in a specified situation. Inference is the act of passing from one proposition, statement, or judgment considered as true to another. The differences in diagnosis, inference, and treatment are explored in greater detail in Table 1, which outlines differences among the health, building science, and urban environment policy sectors.

Table 1 was used to define semi-structured interview questions to explore whether the concepts of diagnosis, inference, treatment, and academic knowledge could be used to explain differences among the professionals reducing heat exposure in Cuyahoga County. 
Table 1: From Academic Knowledge to Preventative Programs

\begin{tabular}{|c|c|c|c|c|c|c|}
\hline & $\begin{array}{c}\text { Academic } \\
\text { Knowledge }^{2}\end{array}$ & $\begin{array}{c}\text { Example } \\
\text { Authors/Studies }\end{array}$ & Diagnoses $^{2}$ & $\begin{array}{l}\text { Methods of } \\
\text { Inference }^{2}\end{array}$ & Treatments ${ }^{2}$ & $\begin{array}{c}\text { Preventative } \\
\text { Programs }\end{array}$ \\
\hline $\begin{array}{l}\text { Health Policy } \\
\text { Sector }^{1}\end{array}$ & $\begin{array}{l}\text { Medicine, } \\
\text { Industrial } \\
\text { Hygiene, Public } \\
\text { Health, Social } \\
\text { Work, Health } \\
\text { Geography, } \\
\text { Health } \\
\text { Sociology, } \\
\text { Epidemiology }\end{array}$ & $\begin{array}{l}\text { (Budd, 2008; } \\
\text { Kilbourne, } \\
\text { 1982; Minard, } \\
\text { 1957; Semenza } \\
\text { et al., 1996) }\end{array}$ & $\begin{array}{l}\text { Exposure to } \\
\text { high } \\
\text { temperatures } \\
\text { causes illness. } \\
\text { Socioeconomic } \\
\text { status, age, } \\
\text { education, } \\
\text { health, and } \\
\text { environmental } \\
\text { factors are } \\
\text { associated } \\
\text { with increased } \\
\text { exposure. }\end{array}$ & $\begin{array}{l}\text { Case control } \\
\text { studies } \\
\text { investigate the } \\
\text { socioeconomic, } \\
\text { demographic, } \\
\text { and } \\
\text { environmental } \\
\text { factors associated } \\
\text { with increased } \\
\text { morbidity and } \\
\text { mortality. }\end{array}$ & $\begin{array}{l}\text { Reduce } \\
\text { exposure in } \\
\text { vulnerable } \\
\text { populations } \\
\text { by tempering } \\
\text { the thermal } \\
\text { environment. } \\
\text { d }\end{array}$ & $\begin{array}{l}\text { Heat health } \\
\text { warning systems, } \\
\text { messaging, } \\
\text { cooling centers, } \\
\text { neighborhood } \\
\text { watch programs, } \\
\text { air-conditioning } \\
\text { installation }\end{array}$ \\
\hline $\begin{array}{l}\text { Building Policy } \\
\text { Sector }^{1}\end{array}$ & $\begin{array}{l}\text { Mechanical } \\
\text { and Electrical } \\
\text { Engineering, } \\
\text { Building } \\
\text { Science, } \\
\text { Economics, } \\
\text { Environment } \\
\text { and Behavior, } \\
\text { Behavioral } \\
\text { Psychology }\end{array}$ & $\begin{array}{l}\text { (de Dear \& } \\
\text { Schiller Brager, } \\
\text { 1998; Fanger, } \\
\text { 1972; Hoppe, } \\
\text { 1999; Nicol \& } \\
\text { Humphreys, } \\
\text { 1973) }\end{array}$ & $\begin{array}{l}\text { Building } \\
\text { occupants } \\
\text { require a } \\
\text { certain range of } \\
\text { indoor thermal } \\
\text { environmental } \\
\text { conditions to } \\
\text { achieve thermal } \\
\text { comfort. }\end{array}$ & $\begin{array}{l}\text { Studies } \\
\text { investigate } \\
\text { the thermal } \\
\text { environmental } \\
\text { and personal } \\
\text { variables } \\
\text { that predict } \\
\text { comfortable } \\
\text { conditions. }\end{array}$ & $\begin{array}{l}\text { HVAC or } \\
\text { passive systems } \\
\text { provide } \\
\text { comfortable } \\
\text { indoor } \\
\text { conditions for } \\
\text { the occupants. }\end{array}$ & $\begin{array}{l}\text { Emerging } \\
\text { technologies, } \\
\text { energy efficiency, } \\
\text { weatherization, } \\
\text { low-income } \\
\text { energy assistance }\end{array}$ \\
\hline $\begin{array}{l}\text { Urban Policy } \\
\text { Sector }^{1}\end{array}$ & $\begin{array}{l}\text { Civil and } \\
\text { Environmental } \\
\text { Engineering, } \\
\text { Urban Climate, } \\
\text { Landscape } \\
\text { Architecture, } \\
\text { Urban and Re- } \\
\text { gional Planning, } \\
\text { Urban Sociol- } \\
\text { ogy }\end{array}$ & $\begin{array}{l}\text { (Harlan, Brazel, } \\
\text { Prashad, Ste- } \\
\text { fanov, \& Larsen, } \\
\text { 2006; Klinen- } \\
\text { berg, 2002; Tim } \\
\text { R. Oke, 1982; } \\
\text { Reid et } \\
\text { al., 2009; } \\
\text { Santamouris, } \\
\text { Synnefa, \& } \\
\text { Karlessi, 2011) }\end{array}$ & $\begin{array}{l}\text { The urban heat } \\
\text { island effect } \\
\text { increases energy } \\
\text { consumption, } \\
\text { pollutes air, } \\
\text { compromises } \\
\text { human health, } \\
\text { and impairs } \\
\text { water quality. }\end{array}$ & $\begin{array}{l}\text { Experimental } \\
\text { and quasi- } \\
\text { experimental } \\
\text { field studies } \\
\text { investigate the } \\
\text { biophysical vari- } \\
\text { ables that cause } \\
\text { the urban heat } \\
\text { island effect. }\end{array}$ & $\begin{array}{l}\text { Improvements } \\
\text { in land cover, } \\
\text { urban geometry, } \\
\text { heat capacity, } \\
\text { and anthro- } \\
\text { - pogenic heat } \\
\text { sources mitigate } \\
\text { the urban heat } \\
\text { island effect. }\end{array}$ & $\begin{array}{l}\text { Street tree plant- } \\
\text { ing, zoning, } \\
\text { architectural } \\
\text { standards, } \\
\text { paving specifica- } \\
\text { tions, energy } \\
\text { efficiency }\end{array}$ \\
\hline
\end{tabular}

1. Concept of policy sectors adapted from Strengers and Maller (2011).

2. Concept of academic knowledge, diagnosis, inference, and treatment adapted from Abbott (1988).

3. Preventative programs are city, county, state, federal and non-governmental programs that provide services such as airconditioning installation, energy efficiency, street tree planting, or public education/outreach.

\subsection{Research Questions}

We structured this research around two questions. The first question was: "How do professionals define issues related to temperature in the built environment?" Based on the system of professions framework, we hypothesized that professionals have 
different diagnoses, methods of inference, and treatments of temperature-related issues in the built environment.

The second research question was: "How do professionals act on issues related to temperature in the built environment?" We analyzed two hypotheses, derived from the system of professions framework and from Janda and Parag (2013). First, professionals simplify treatments to increase program efficiency. Second, professionals are middle-out actors who work upstream by participating in the policy process, downstream to assist program implementation, and sideways to influence local decision-making.

\section{Methods}

We used two primary methods to collect data. The first was a review of official documents from the weatherization, urban environment, and heat health programs at the city, county, state, and federal levels. We also participated in a week-long, hands-on weatherization training program, attended two national weatherization and health conferences, and observed a sustainability summit sponsored by the City of Cleveland.

Drawing on these experiences, we then developed questions for semi-structured interviews with program staff. The questions were based on concepts from the system of professions and focused on five areas: (1) career and educational background, (2) agency structure, (3) collaboration, (4) innovation, and (5) program evaluation. We also developed recruitment emails, consent forms, and an interview checklist to ensure consistency among all of the interviews. These protocols were reviewed by the University of Michigan Institutional Review Board, Registration Number IRB00000246.

Beginning with the names of city staff we had identified from the program documentation, we began to schedule and interview program managers. Interviews ranged from approximately 45 minutes to more than two hours in length. At the end of each interview, we asked the participant for contact information for additional interview participants; this snowball sampling method is commonly used in qualitative interviewing (Weiss, 1994). In total, we conducted 28 semi-structured interviews with 32 people from the health, building science, and urban/neighborhood policy communities.

Table 2 presents the characteristics of the interviewees by sector. Twenty of the interviewees were male ( 62.5 percent) and 12 were female (37.5 percent). Eleven of 
Table 2: Interviewee Characteristics by Sector

\begin{tabular}{lcccc}
\hline Characteristic & Health & Building Science & Urban Environment & Row Total \\
\hline Male & $5(15.6 \%)$ & $7(21.9 \%)$ & $8(25.0 \%)$ & $20(62.5 \%)$ \\
Female & $6(18.8 \%)$ & $3(9.4 \%)$ & $3(9.4 \%)$ & $12(37.5 \%)$ \\
$\quad$ Column Total & $11(34.4 \%)$ & $10(31.2 \%)$ & $11(34.4 \%)$ & $32(100 \%)$ \\
City/County & $4(12.5 \%)$ & $5(15.6 \%)$ & $6(18.8 \%)$ & $15(46.9 \%)$ \\
State & 0 & $2(6.2 \%)$ & 0 & $2(6.2 \%)$ \\
Federal & $1(3.1 \%)$ & $2(6.2 \%)$ & $1(3.1 \%)$ & $4(12.5 \%)$ \\
Non-Governmental & $4(12.5 \%)$ & $3(9.4 \%)$ & $4(12.5 \%)$ & $11(34.4 \%)$ \\
$\quad$ Column Total & $9(28.1 \%)$ & $12(37.5 \%)$ & $11(34.4 \%)$ & $32(100 \%)$ \\
\hline
\end{tabular}

the interviewees were from the health sector (34.4 percent), 10 were from the building science sector (31.2 percent), and 11 were from the urban environment sector (34.4 percent). The majority of the professionals worked at the city and county levels (46.9 percent), though we also interviewed professionals at the state (9.4 percent) and federal (9.4 percent) levels. Roughly a third of the interviewees (34.3 percent) were from non-governmental organizations that worked at all three levels.

Audio recordings of the interviews were transcribed by a professional transcriptionist; we checked the transcripts for accuracy and entered them into the cloudhosted Dedoose software for coding and analysis (Lieber \& Weisner, 2010; SocioCultural Research Consultants, 2014).

\section{Results}

Consistent with the Abbott (1988) system of professions, we found that professionals have different diagnoses and methods of inference for temperature-related issues in the built environment. These differences are aligned along the health, building science, and urban environment policy sectors.

However, while diagnoses and methods of inference were different for each of the policy sectors, there were some overlaps in the treatments discussed during the interviews. Professionals described 13 different treatments that they felt were effective in reducing exposure to temperature (Figure 1).

Air-conditioning, energy efficiency, indoor air quality, insulation, and mechanical system efficiency were mentioned by all three policy sectors. Green infrastructure, cooling centers, increases in albedo, messaging, and heat warning systems were 


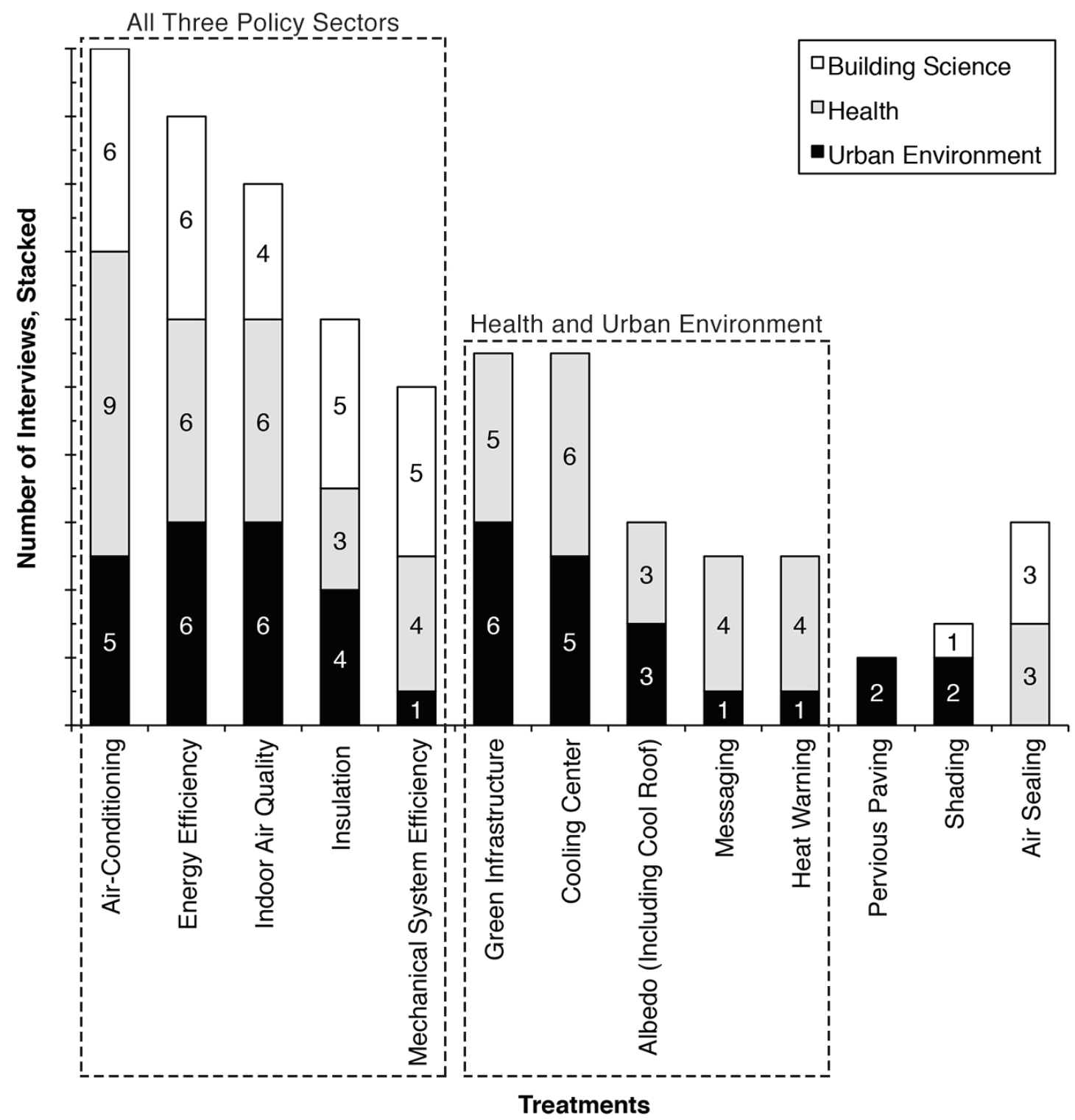

Figure 1: Treatments Discussed by Sector (Note: Treatments were counted only once per interviewee. Treatment types were narrowly coded; interviewees had to mention that the strategy was used by their program or that they felt it might be an effective way to reduce exposure.) 
discussed in interviews only in the health and the urban environment policy sectors. Finally, pervious paving, shading, and air sealing were only discussed by a small number of professionals from one or two of the sectors.

Air-conditioning, energy efficiency, and indoor air quality protection were the only treatments discussed by a large fraction of interviewees from all three sectors. In addition, several strategies like pervious paving, shading, and air sealing were mentioned by only one or two of the sectors. In general, professionals from the urban environment sector discussed the widest range of strategies, and building scientists mentioned the narrowest number.

\subsection{Simplification of treatments}

Abbott (1988) describes the conversion of professional knowledge into a commodity that can be bought and sold without the direct involvement of a profession. Abbott provides examples from law, architecture, and the social sciences; these professional commodities include fixed legal forms, house plans, and statistical analyses (Ibid., 146). Because professionals in Cuyahoga County did not sell their professional knowledge in a condensed form, we use the term "simplify" instead of "commodify" throughout.

In the interviews in Greater Cleveland, we found that professionals simplify treatments to increase program efficiency and to aid in evaluation. Across all three of the policy sectors, the process used to simplify treatments was similar; it was described as the creation of a template or tool for others to use (35.7 percent), as the standardization of treatments (50 percent), or as the sharing of data among organizations (14.3 percent).

For example, rather than allowing each local jurisdiction to develop heat warning messages, federal health professionals provide templates to local agencies to ensure consistency in public messaging about heat waves; local professionals in turn coordinate and share these announcements with the public.

In a similar way, the Ohio weatherization program initially provided services on a case-by-case basis, leaving selection and implementation of strategies to local building professionals. Over time, research redefined insulation and air sealing as the two most important strategies to improve energy efficiency and comfort in a home. To reduce errors during installation, state officials created standards to guide these processes.

In the urban environment sector, data sharing among organizations facilitates coordination among agencies. Several interviewees mentioned an effort by Case 
Western Reserve University called the Northeast Ohio Community and Neighborhood Data for Organizing (NEO CANDO). According to the NEO CANDO (2012) website, staff at the university compile data from a wide variety of federal, state, and local organizations, clean the data, create consistent formatting, and upload it to a password-protected website. In this case, data created by professionals is open for public interpretation; their professional judgment is no longer needed to map trends in the region.

\subsection{Professionals as middle-out actors}

Consistent with Janda and Parag (2013), we found that professionals in all three policy sectors are middle-out actors, and that they work upstream by participating in the policy process, downstream to assist program implementation, and sideways to influence local decision-making (Figure 2). The interviews indicate that all three of the sectors use similar tactics; there are no significant tactical differences among health, building science, and urban environment professionals. The following three subsections describe these upstream, downstream, and sideways processes.

Upstream: In working upstream to influence policy formation, more than twothirds of the professionals interviewed (71.4 percent) participated in advocacy efforts, served on a policy committee, or had a direct advisory role for their program. Slightly more than a quarter of the interviewees ( 28.6 percent) provided data to help formulate policy. Others ( 7.1 percent) participated in regularly scheduled meetings to discuss program management with policymakers.

For example, a series of pediatric deaths in Cleveland led to changes in how the U.S. Department of Housing and Urban Development (HUD) addresses environmental hazards across the United States. As early as 1993, local hospital officials noticed that there was a cluster of infant mortality occurring in low-income and minority households. They received permission from parents to autopsy the children to determine the cause and found a rare condition of the lungs called pulmonary hemosiderosis (Jacobs et al., 2007). Hypothesizing that the children had been exposed to something in the air in their homes, they visited their houses and discovered a unique configuration of ductwork called the "Cleveland Drop."

In the Cleveland Drop, the return air ducts from living spaces are not connected to the furnace; instead, they are open to the basement air. In many homes, the open return air ductwork was placed at each of the four corners of a house, the maximum distance from the heating element, to ensure that the return air had to travel across the basement. While no literature describes why contractors installed this configu- 


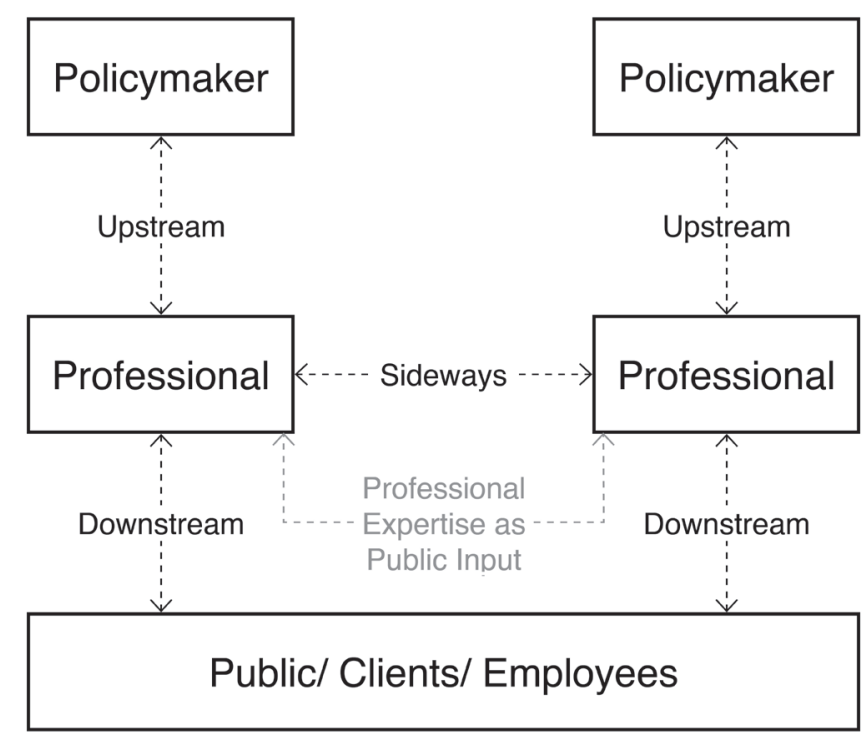

Figure 2: Professionals Collaborating Through Middle-Out Actions (Adapted from Janda and Parag 2013)

ration in Northeast Ohio homes, local weatherization officials speculated that it may have been a way to keep basements dry, that it was less expensive, or that it was a way to provide low-cost cooling in summer. Unfortunately, this unique ductwork configuration appears to have caused the pulmonary hemosiderosis by contaminating the indoor air with moisture and mold from the basement.

In testimony before the U.S. House of Representatives (Testimony of Members of Congress and Other Interested Individuals and Organizations, 1998), two local health officials asked Congress to provide additional funding to address environmental hazards in homes. One of the members of Congress, Louis Stokes, was the representative for the City of Cleveland. Louis Stokes then worked with Congress to restructure the HUD Office of Lead Hazard Control into a new organization with a broader focus on health issues in the home (U.S. Congress, 1998).

Although this example of professionals working upstream is only indirectly related to temperature exposure, it is a clear example of how professionals can influence the policy process. In addition, the "Office of Lead Hazard Control and Healthy Homes" initiated by Louis Stokes at HUD is responsible for reducing 
health-related issues in the home; one of the major risk factors recently identified is a lack of indoor temperature control (Federal Healthy Homes Work Group, 2013). Similar examples occurred in the building science and urban environment sectors, though none of the other cases had as dramatic of an impact on national policy.

Downstream: In working downstream, more than half of the professionals interviewed participate in community meetings (60.7 percent), collaborate on research (32.1 percent), or serve as a consultant to projects (7.1 percent). In one example, urban designers are working with neighborhoods to find new purposes for vacant properties, a significant issue in Cleveland (Dewar, 2006).

In this example, urban environment professionals are interpreting a consent decree agreed to by the Northeast Ohio Regional Sewer District and the U.S. Environmental Protection Agency ("United States of America and State of Ohio v. Northeast Ohio Regional Sewer District," 2011) to reduce combined sewer overflows into Lake Erie. Their goal is to reutilize vacant land throughout the county.

Working with local nonprofits, urban environment professionals are using their knowledge to show how vacant land can be repurposed for stormwater capture and rain gardens to reduce combined sewer overflows into Lake Erie. They are also developing pilot projects in distressed neighborhoods to increase the amount of tree canopy in the city. While their primary goals are to reutilize the large number of vacant properties and to reduce the discharge of sewage into the lake, they said in the interviews that their efforts will have environmental co-benefits like climate resilience. This shows how professionals can interpret policy and work with local organizations downstream to implement the policy process.

Sideways: Education and training (39.3 percent) and tool kits (21.4 percent) were the two primary ways that professionals worked sideways to influence other professionals in their work. For example, the Office of Emergency Management in Cuyahoga County recently held a "table top" training exercise to examine heatrelated vulnerability. The exercise emphasized collaboration among professionals from local agencies.

After the exercise, the county emergency management staff sent sample policies and procedures prepared by other cities as a tool kit to help each agency prepare its strategy. The hope was that in the event of an actual emergency, the new professional networks created during the tabletop exercise would expedite communication, and the sample documents would create consistency among jurisdictions. This example shows how professionals can work sideways to influence the work of other organizations; all three policy sectors engaged in similar efforts. 


\section{Discussion}

The interviews confirmed that professionals in the health, building science, and urban environment policy sectors define issues related to temperature in the built environment differently. Each of the sectors has different sets of academic knowledge; this results in different diagnoses, methods of inference, and treatments of temperature-related issues in the built environment. Only air-conditioning, energy efficiency, and indoor air quality protection were discussed by the majority of interviewees from all three sectors; this indicates a potential disconnect among policy sectors regarding strategies.

Air-conditioning, energy efficiency, and indoor air quality protection all target exposure at the household level. It is not surprising, then, that these interviews revealed conflicts between the health and building science sectors over the installation of air-conditioning in homes. However, although they were not discussed directly in the interviews we conducted, we found that other conflicts arise among policy sectors, like between health and the urban environment, or the urban environment and building science. These conflicts were not highlighted in the interviews either because professionals in Cuyahoga County do not see this part of heat exposure as being interrelated or because funding is siloed among their programs. Figure 3 explores these additional conflicts.

For example, in a temperate climate like Northeast Ohio, installing a treatment like a light-colored roof on a house to mitigate the urban heat island effect might reduce indoor and outdoor temperatures, but it might also increase wintertime energy use because it reflects away solar heat gain in winter. Because the weatherization programs deal only with improving heating season energy performance, installing this treatment creates a conflict between the urban environment and building science policy sectors.

Other potential conflicts may arise between the health and urban environment sectors around the installation of air-conditioning. While air-conditioning may help to reduce temperature inside buildings, the waste heat produced by the system contributes to the urban heat island effect. In addition, in much of the United States, the electricity used to power air-conditioning equipment is generated by combusting fossil fuels; this contributes to the broader issue of global warming. Although these issues represent additional conflicts, they may also offer opportunities to bring professionals together to address heat exposure in cities. 


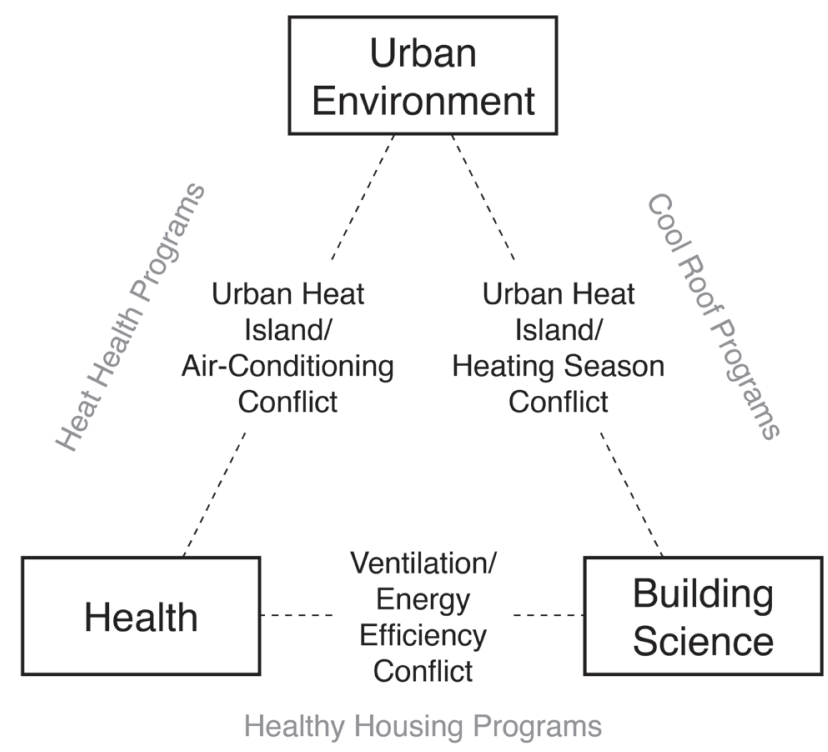

Figure 3: Conflicts among the Health, Building Science, and Urban Environmental Sectors (adapted from Campbell, 1996)

\subsection{Addressing issues}

The interviews confirmed that professionals address heat exposure differently, though the processes they use are similar. For example, the professionals in all three policy sectors described ways that they simplify treatments to increase program efficiency and to aid in evaluation (Abbott 1988). Professionals also described working as middle-out actors who work upstream by participating in the policy process, downstream to assist program implementation, and sideways to influence local decision-making (Janda and Parag 2013).

Although simplification improves the efficiency of programs, it also appears to create barriers among programs. For example, the weatherization program has a very specific set of metrics to evaluate program performance: kilowatt-hours and therms of natural gas usage. These two metrics are used to compute cost effectiveness and to demonstrate the program's ability to reduce wintertime heating costs. However, these metrics do not capture the effect of the programs on summertime 
electrical demand, which utilities typically measure as a reduction in total kilowatts. Because the weatherization program omits kilowatts as part of its program evaluation, it does not count the positive benefits of weatherization on peak loads, a potential co-benefit of the weatherization program.

If weatherization programs collected this data, they could not only take credit for these benefits, but also facilitate coordination around the issue of heat exposure. For example, planting of deciduous trees by an urban environment program would have limited effect on wintertime heating performance in homes, but it should help to reduce summertime electrical demand from air-conditioning. Using a common metric, the two programs could then work together to achieve mutually beneficial goals.

To make such coordination possible, professionals need to be willing to regularly revisit how they define treatments. Weatherization programs have not changed the treatments or the metrics they use because their strategies and evaluation protocols have been extremely successful from the perspective of cost-effectiveness. However, given recent reductions in state and federal funding, it might be wise for programs to engage in experimentation and limited pilot projects that could lead to new directions (Sullivan, 2009). These efforts could be supported by local foundations, which have already funded projects related to healthy housing and vacant land.

However, the simplification of professional knowledge can have positive benefits for a profession. For example, many professionals create data specifically for policymakers, provide "tool kits" to peer organizations to assist with decision-making, or use their professional skills to help local agencies achieve their goals. Although it may take a major event like the cluster of pulmonary hemosiderosis to catalyze changes in policy, these proactive efforts of local professionals encourage these dialogues to occur.

\subsection{Overcoming barriers}

The interviews confirmed that differences in priorities can cause conflict among programs; however, these conflicts were primarily limited to the health and building science sectors. Although Abbott (1988) might argue that conflicts are the primary way that professionals compete with one another to protect their jurisdictions, we found that there is significant interest among the professionals in working together to address issues related to climate change.

Professionals may be willing to work together in the sectors of health, building science, and urban environment because they do not regularly come into conflict 
over resources. However, this very lack of open competition may actually impede regular collaboration, because these professionals may not view their work as interdependent. Just as foundation support helped to bridge the health and building science sectors to address lead poisoning, and to bridge the building science and urban environment sectors to address stormwater management and vacant land, it may be possible to use foundation support in Cuyahoga County to create new programs to engage multiple sectors around heat exposure.

This process would be different from typical collaborative planning efforts, which seek to elevate underrepresented communities to stakeholder status using participatory approaches. Rather than direct participation in the formation of crosscutting heat exposure policy, which is unlikely to draw much interest from the general public, these professionals from the health, building science, and urban environment policy sectors might work downstream to encourage public input for each of their programs individually, and then mediate relationships sideways with other sectors. Using official channels, they might then influence policymakers upstream to reduce siloes among programs and have more leverage for their claims because they have initiated a public process to substantiate their policy recommendations.

While there is some concern over the amount of resources participants need to contribute to such a process, the concept of collaborative planning may be transferrable to the issue of heat exposure in Cuyahoga County and other cities (Innes \& Booher, 2004). Research that supports communicative action—such as the research presented in this chapter - can lead to new identities, meanings, heuristics, and innovation that may help communities adapt to future challenges like extreme heat events or other climate-related surprises (Innes \& Booher, 2010; Schneider, 2004).

\subsection{Takeaways for practice}

To this end, a recent planning effort led by a local non-profit, Cleveland Neighborhood Progress, has attempted to formalize the above middle-out approach to address climate resilience in four Cleveland neighborhoods. With seed funding from the Kresge Foundation "Climate Resilience and Urban Opportunity Initiative," Cleveland Neighborhood Progress hosted a number of meetings in 2015 to discuss how climate change may impact four neighborhoods in Cleveland. One of the three areas of concern related to climate change identified in their original grant proposal was the potential for increased heat-related morbidity and mortality.

The effort led by Cleveland Neighborhood Progress also generated a series of climate adaptation strategies, including ideas to reduce heat stress at the house-, parcel-, 
block-, neighborhood-, and city-level. These ideas were developed by a multidisciplinary team from three regional universities (Kent State University, University at Buffalo, and the University of Michigan), and were incorporated into a formal Climate Action Plan (http://resilientcleveland.org/) that was submitted to the Kresge Foundation at the end of 2015 for additional funding. At the time of this article's publication, the efforts by Cleveland Neighborhood Progress are just getting underway; in partnership with the City of Cleveland, community development corporations, and local universities, they plan to address climate change over the next three years using the "middle-out" approach described in this article.

For example, working upstream, the City of Cleveland will ensure that the revised Climate Action Plan contains adaptation strategies that align with those discussed in city planning documents. Working downstream, Cleveland Neighborhood Progress will work to complete a series of pilot climate resilience projects in four local neighborhoods working with community development corporations and local residents. And finally, working sideways, Kent State University and the University at Buffalo will evaluate the effectiveness of the neighborhood projects, providing a critical feedback loop to incorporate "lessons learned" into other climate resilience efforts currently underway in the Great Lakes Region.

\section{Conclusions}

This paper described the system of professions involved in reducing exposure to heat stress in Cuyahoga County. While professionals play a critical role in limiting heat-related morbidity and mortality, a limitation of this study is that it focused exclusively on professional communities; interactions among professionals, policymakers, and the public were not examined. Expanding the scope of this research to engage high-level policymakers and the public may help to further explain gaps, barriers, and conflicts that limit coordination and collaboration and help to extend this ecological model.

Interviews with officials confirmed that differences exist in the approaches used by the health, building science, and urban environment sectors. Although issues of heat-related mortality, energy security, and climate change are interconnected, policies regarding access to air-conditioning, energy efficiency, and the urban heat island effect are not coordinated and may contradict one another.

Only three strategies-energy efficiency, air-conditioning, and indoor air quality-were mentioned by the majority of interviewees from all three sectors. 
Other strategies, like cooling centers, improving heating/cooling system efficiency, or green infrastructure were mentioned by a majority of professionals in only one policy sector, indicating a disconnect among professions.

Interviews also revealed ways in which professionals simplify treatments. Professionals used language that was consistent with working as a middle-out actor; they work upstream by participating in the policy process, downstream to assist program implementation, and sideways to influence local decision-making. Interviewees described a notable example in which Cleveland researchers lobbied Congress to create a new federal healthy housing program.

Interviews confirmed that differences in priorities can cause conflict among policy sectors. However, in the interviews, direct conflicts were limited to the health and housing sectors over the issue of energy use versus indoor air quality in homes. Although this conflict could be considered an example of how professionals compete with one another to protect their jurisdictions, we found that the professionals were interested in working together to address issues related to climate change. This is timely because Cleveland and a number of other cities in the Midwest are currently developing climate change plans to improve climate resilience. Encouraging professional communities to work together in cities will be critical to ensure durable and sustainable policies and programs.

\section{Acknowledgments}

Support for this research was provided by the National Science Foundation (NSF) Graduate Research Fellowship under Grant Number DGE 0718128. Support was also received from both the Graham Sustainability Institute and the Energy Institute at the University of Michigan. The Kresge Foundation provided funding for climate resilience planning from their Climate Resilience and Urban Opportunity Initiative to Cleveland Neighborhood Progress, the City of Cleveland, Kent State University, and the University at Buffalo. The authors would like to thank the editors of the Michigan Journal of Sustainability and the three reviewers for valuable feedback and edits to this article. Nicholas Rajkovich would like to thank his dissertation committee (Marie S. O'Neill, Scott D. Campbell, and Richard K. Norton) for invaluable advice throughout the research and writing process. 


\section{References}

Abbott, A. (1988). The System of Professions: An Essay on the Division of Expert Labor. Chicago: The University of Chicago Press.

Altman, P., Lashof, D., Knowlton, K., Chen, E., Johnson, L., \& Kalkstein, L. (2012). Killer Summer Heat: Projected Death Toll from Rising Temperatures in America Due to Climate Change. Retrieved from http://www.nrdc.org/globalwarming/killer-heat/

Anderson, B. G., \& Bell, M. L. (2009). Weather-related mortality: how heat, cold, and heat waves affect mortality in the United States. Epidemiology, 20(2), 205-213. doi:10.1097/ EDE.0b013e318190ee08

Blanco, H., Alberti, M., Forsyth, A., Krizek, K., Rodriguez, D., Talen, E., \& Ellis, C. (2009). Hot, congested, crowded and diverse: Emerging research agendas in planning. Progress in Planning, 71, 153-205. doi:10.1016/j.progress.2009.03.001

Braga, A. L., Zanobetti, A., \& Schwartz, J. (2002). The effect of weather on respiratory and cardiovascular deaths in 12 U.S. cities. Environ Health Perspect, 110(9), 859-863. Retrieved from http://www.ncbi.nlm.nih.gov/pubmed/12204818

Budd, G. M. (2008). Wet-bulb globe temperature (WBGT)--its history and its limitations. J Sci Med Sport, 11(1), 20-32. doi:10.1016/j.jsams.2007.07.003

Campbell, S. (1996). Green Cities, Growing Cities, Just Cities?: Urban Planning and the Contradictions of Sustainable Development. Journal of the American Planning Association, 62(3), 296-312. doi:10.1080/01944369608975696

Case Western Reserve University. (2012). Northeast Ohio Community and Neighborhood Data for Organizing (NEO CANDO). Retrieved from http://neocando.case.edu/index.shtml

CDC. (2009). Extreme Heat: A Prevention Guide to Promote Your Personal Health and Safety. Retrieved from http://www.bt.cdc.gov/disasters/extremeheat/heat_guide.asp

Chestnut, L. G., Breffle, W. S., Smith, J. B., \& Kalkstein, L. S. (1998). Analysis of differences in hot-weather-related mortality across 44 U.S. metropolitan areas. Environmental Science \& Policy, 1(1), 59-70. doi:10.1016/s1462-9011(98)00015-x

Corburn, J. (2009). Toward the Healthy City. Cambridge, MA: MIT Press.

Dagenhart, R., \& Sawicki, D. (1992). Architecture and Planning: The Divergence of Two Fields. Journal of Planning Education and Research, 12, 1-16.

de Dear, R. J., \& Schiller Brager, G. (1998). Developing an Adaptive Model of Thermal Comfort and Preference. ASHRAE Transactions, 104, 145-167.

Dewar, M. (2006). Selling Tax-Reverted Land: Lessons from Cleveland and Detroit: New This Spring Westchester. Journal of the American Planning Association, 72(2), 167-180. doi: $10.1080 / 01944360608976737$

EPA. (2012). Tapping Green Infrastructure to Curb Sewer Overflows. Retrieved from http://www. epa.gov/sciencematters/april2012/overflows.htm

Fanger, P. O. (1972). Thermal comfort: analysis and applications in environmental engineering. New York: McGraw-Hill.

Federal Healthy Homes Work Group. (2013). Advancing Healthy Housing: A Strategy for Action. Retrieved from http://portal.hud.gov/hudportal/documents/huddoc?id=AHHASA_2-19.pdf

Fischer, F. (2000). Citizens, Experts, and the Environment. Durham, NC: Duke University Press.

Guy, S., \& Shove, E. (2000). A Sociology of Energy, Buildings and the Environment: Constructing knowledge, designing practice. 
Hajer, M. A. (1995). The Politics of Environmental Discourse: Ecological Modernization and the Policy Process. London: Oxford University Press.

Harlan, S. L., Brazel, A. J., Prashad, L., Stefanov, W. L., \& Larsen, L. (2006). Neighborhood microclimates and vulnerability to heat stress. Soc Sci Med, 63(11), 2847-2863. doi:10.1016/j. socscimed.2006.07.030

Henn, R. L. (2013). Moving Targets: Managing Interinstitutional Relationships in Green Building Design and Construction. (Doctor of Philosophy), University of Michigan, Ann Arbor, Michigan.

Hoppe, P. (1999). The physiological equivalent temperature-a universal index for the biometeorological assessment of the thermal environment. Int J Biometeorol, 43(2), 71-75. Retrieved from http://www.ncbi.nlm.nih.gov/pubmed/10552310

Innes, J. E., \& Booher, D. E. (2004). Reframing Public Participation: Strategies for the 21st Century. Planning Theory \& Practice, 5(4), 419-436.

Innes, J. E., \& Booher, D. E. (2010). Planning With Complexity: An introduction to collaborative rationality for public policy. New York, NY: Routledge.

Jacobs, D. E., Kelly, T., \& Sobolewski, J. (2007). Linking public health, housing, and indoor environmental policy: successes and challenges at local and federal agencies in the United States. Environ Health Perspect, 115(6), 976-982. doi:10.1289/ehp.8990

Janda, K. B., \& Killip, G. (2013). Building Expertise: Renovation as Professional Innovation. In R. L. Henn \& A. J. Hoffman (Eds.), Constructing Green: The Social Structures of Sustainability (pp. 35-55). Cambridge, MA: MIT Press.

Janda, K. B., \& Parag, Y. (2013). A middle-out approach for improving energy performance in buildings. Building Research \& Information, 41(1), 39-50. doi:10.1080/09613218.2013.743 396

Keatinge, W. R. (2003). Death in heat waves. BMJ, 327(7414), 512-513. doi:10.1136/ bmj.327.7414.512

Kilbourne, E. M. (1982). Risk Factors for Heatstroke. Jama, 247(24), 3332. doi:10.1001/ jama.1982.03320490030031

Klinenberg, E. (2002). Heat wave: a social autopsy of disaster in Chicago. Chicago: University of Chicago Press.

Larson, M. S. (2013). The Rise of Professionalism. New Brunswick, NJ: Transaction Publishers.

Lieber, E., \& Weisner, T. S. (2010). Meeting the Practical Challenges of Mixed Methods Research. In A. Tashakkori \& C. Teddlie (Eds.), Sage Handbook of Mixed Methods in Social \& Behavioral Research, 2nd Edition (pp. 559-580). Thousand Oaks, CA: Sage Publications, Inc.

Luber, G., \& McGeehin, M. (2008). Climate Change and Extreme Heat Events. American Journal of Preventitive Medicine, 35(5), 429 - 435. doi:10.1016/j.amepre.2008.08.021

Maller, C. J., \& Strengers, Y. (2011). Housing, heat stress and health in a changing climate: promoting the adaptive capacity of vulnerable households, a suggested way forward. Health Promot Int, 26(4), 492-498. doi:10.1093/heapro/dar003

Melillo, J. M., Richmond, T., \& Yohe, G. W. (2014). Climate Change Impacts in the United States: The Third National Climate Assessment. Washington, D.C.: U.S. Global Change Research Program.

Minard, D. (1957). Prevention of Heat Casualties. Journal of the American Medical Association, 165(14), 1813. doi:10.1001/jama.1957.02980320043010

Nicol, F., \& Humphreys, M. (1973). Thermal comfort as part of a self-regulating system. Building Research and Practice, 6(3), 191-197. 
O’Neill, M. S., Carter, R., Kish, J. K., Gronlund, C. J., White-Newsome, J. L., Manarolla, X., ... Schwartz, J. D. (2009). Preventing heat-related morbidity and mortality: new approaches in a changing climate. Maturitas, 64(2), 98-103. doi:10.1016/j.maturitas.2009.08.005

Oke, T. R. (1982). The energetic basis of the urban heat island. Quarterly Journal of the Royal Meteorological Society, 108(455), 1-24.

Oke, T. R. (2006). Towards better scientific communication in urban climate. Theoretical and Applied Climatology, 84(1-3), 179-190. doi:10.1007/s00704-005-0153-0

Reid, C., O’Neill, M. S., Gronlund, C. J., Brines, S. J., Brown, D. G., Diez-Roux, A. V., \& Schwartz, J. (2009). Mapping community determinants of heat vulnerability. Environmental Health Perspectives, 117(11), 1730-1736. doi:doi:10.1289/ehp.0900683

Sabatier, P. A., \& Weible, C. M. (2007). The Advocacy Coalition Framework: Innovations and Clarifications. In P. A. Sabatier (Ed.), Theories of the Policy Process, 2nd Edition. Cambridge, MA: Westview Press.

Santamouris, M., Synnefa, A., \& Karlessi, T. (2011). Using advanced cool materials in the urban built environment to mitigate heat islands and improve thermal comfort conditions. Solar Energy, 85(12), 3085-3102. doi:10.1016/j.solener.2010.12.023

Schneider, S. H. (2004). Abrupt non-linear climate change, irreversibility and surprise. Global Environmental Change, 14(3), 245-258. doi:10.1016/j.gloenvcha.2004.04.008

Semenza, J. C., Rubin, C. H., Falter, K. H., Selanikio, J. D., Flanders, W. D., Howe, H. L., \& Wilhelm, J. L. (1996). Heat related deaths during the July 1995 heat wave in Chicago. N Engl J Med, 335(2), 84-90. doi:10.1056/NEJM199607113350203

SocioCultural Research Consultants. (2014). About Us: Qualitative Research and Mixed Methods Research Using Dedoose. Retrieved from http://www.dedoose.com/about-us/

Staudt, A., \& Inkley, D. (2009). More Extreme Heat Waves: Global Warming's Wake Up Call. Retrieved from https://www.nwf.org/pdf/Reports/NWF_Heatwaves_Optimized.pdf

Strengers, Y., \& Maller, C. (2011). Integrating health, housing and energy policies: social practices of cooling. Building Research \& Information, 39(2), 154-168. doi:10.1080/09613218.2011.5 62720

Sullivan, M. J. (2009). Using Experiments to Foster Innovation and Improve the Effectiveness of Energy Efficiency Programs. Retrieved from Berkeley, CA:

Testimony of Members of Congress and Other Interested Individuals and Organizations, U.S. House of Representatives, 105th Congress Sess (1998).

Departments of Veterans Affairs and Housing and Urban Development, and Independent Agencies Appropriations Act, 1999., 105-276 2461-2680 (1998).

United States of America and State of Ohio v. Northeast Ohio Regional Sewer District (United States District Court for the Northern District of Ohio 2011).

Weiss, R. S. (1994). Learning from Strangers: The Art and Method of Qualitative Interview Studies. New York: The Free Press.

Wilensky, H. L. (1964). The Professionalization of Everyone? American Journal of Sociology, 70(2), 137-158. 